\title{
Effect of Farmyard Manure on Mineral Nutrition of Rye (Secale cerale L.) Plant
}

\author{
Aydin ADİLOĞLU1 ${ }^{1}$ Korkmaz BELLİTÜRK², Sevinç ADİLOĞLU³ ${ }^{3}$ Yusuf SOLMAZ \\ Tekirdağ Namık Kemal University, Faculty of Agriculture, Department of Soil Science and Plant Nutrition, Tekirdağ/Turkey. \\ ${ }^{1}$ https://orcid.org/0000-0002-7926-509X, ${ }^{2}$ https://orcid.org/0000 00034944 3497, ${ }^{3}$ https://orcid.org/0000-0002-0062-0491, \\ ${ }^{4} \mathrm{https}: / /$ orcid.org/0000-0003-2170-0375 \\ $\bowtie$ :ysolmaz@nku.edu.tr
}

\section{ABSTRACT}

This research was conducted to determine the effect of increasing pellet farmyard manure on mineral nutrition of rye (Secale cerale L.) plant. For this purpose, a pot experiment was established in greenhouse conditions with three replications. Five farmyard manure doses $\left(\mathrm{FM}_{0}: 0 \%\right.$, FM1: 4 \%, FM2, $8 \%$, FM3: $12 \%$ and FM4: $16 \%$ ) were applied to pots a month prior to sowing. Nitrogen (14 kg $\mathrm{N}$ da-1), phosphorus (8 kg P2O5 da-1 and potassium (5 kg K2O da-1) were applied to each pot from NH4NO3 and KH2PO4 fertilizers. Rye (Secale cerale L.) was harvested 60 day after planting and dry matter yield and some macro and micro element (N, P, K, Ca, Mg, $\mathrm{Fe}, \mathrm{Cu}, \mathrm{Zn}$ and $\mathrm{Mn}$ ) contents of plants were determined. According to the results, significant increases of dry matter yield of plants were determined with increasing farmyard manure applications. Also, increasing farmyard manure application on $\mathrm{N}, \mathrm{P}, \mathrm{K}, \mathrm{Fe}, \mathrm{Cu}, \mathrm{Zn}$ and Mn contents of rye (Secale cerale L.) were found statistically significant at the level of $5 \%$.

\section{Research Article}

$\begin{array}{ll}\text { Article History } & \\ \text { Received } & : 19.08 .2019 \\ \text { Accepted } & : 08.11 .2019\end{array}$

\section{Keywords}

Farmyard manure

Macro element

Trace element

Rye.

\section{Çiftlik Gübresinin Çavdar (Secale cerale L.) Bitkisinin Mineral Beslenmesine Etkisi}

\section{ÖZET}

$\mathrm{Bu}$ araştırma, artan miktarlarda çiftlik gübresi uygulamasının çavdar bitkisinin (Secale cerale L.) mineral beslenmesi üzerindeki etkisini belirlemek amacıyla yapılmıştır. $\mathrm{Bu}$ amaçla sera koşullarında üç paralelli bir saksı denemesi yapılmıştır. Denemede beş doz pellet haline getirilmiş çiftlik gübresi (Ço: \% 0, С̧1: \% 4, $\mathrm{C}_{2}: \%$ 8, С̧3: \% 12 ve $\mathrm{C}_{4}: \%$ 16) tohum ekiminden bir ay önce uygulanmıştır. Sakslarin her birine $14 \mathrm{~kg} \mathrm{~N}$ da-1, $8 \mathrm{~kg}$ P2O5 kg da-1 ve $5 \mathrm{~kg} \mathrm{~K} 2 \mathrm{O}$ da-1 NH4NO3 ve KH2PO4 gübrelerinden uygulanmıştır. Bitkiler ekimden 60 gün sonra hasat edilmiş ve kuru madde miktarları ile birlikte bazı makro ve mikro bitki besin elementi içerikleri (N, P, K, $\mathrm{Ca}, \mathrm{Mg}, \mathrm{Fe}, \mathrm{Cu}, \mathrm{Zn}$ ve $\mathrm{Mn}$ ) belirlenmiştir. Elde edilen bulgulara göre, artan miktarlarda çiftlik gübresi uygulamaları ile birlikte çavdar bitkisinin kuru madde miktarı üzerinde önemli artışlar saptanmıştır. Ayrıca çiftlik gübresinin artan miktarları ile çavdar bitkisinin $\mathrm{N}, \mathrm{P}, \mathrm{K}, \mathrm{Fe}, \mathrm{Cu}, \mathrm{Zn}$ ve $\mathrm{Mn}$ içeriklerinde de $\% 5$ düzeyinde önemli artışlar olduğu görülmüştür.
Araştırma Makalesi

Makale Tarihçesi
Geliş Tarihi $\quad: 19.08 .2019$
Kabul Tarihi

Anahtar Kelimeler

Çiftlik gübresi

Makro besin elementi

Mikro besin elementi

Çavdar

To Cite : Bellitürk K, Adiloğlu A, Adiloğlu S, Solmaz Y 2020. Effect of Farmyard Manure on Mineral Nutrition of Rye (Secale cerale L.) Plant. KSU J. Agric Nat 23 (2): 316-320. DOI: 10.18016/ksutarimdoga.vi.606574.

\section{INTRODUCTION}

In the last century, the developed countries, that were trying to solve the nutrition problem of humanity, have proposed to use fertilizers that are more chemical on unit area in order to increase productivity in agriculture. However, even the yields may have increased by the application of more chemical fertilizers on the unit area; this caused serious impairment of product quality, environmental pollution, especially the pollution of natural sources, notably soil and water resources, and important health problems on the living beings.

In recent years, scientists tried to solve the problem caused by chemical fertilizers and revealed the need for the use of organic fertilizers. One advantage of organic fertilizers is that they have a capacity to 
eliminate the pollution of soil and water resources caused by chemical fertilizers. Several kinds of organic fertilizers have been intensely used in agriculture lately.

In a study carried out in Chile, some plant nutrient contents of aquaculture wastes were analyzed for agricultural use. Some plant nutrient macro elements of the aquaculture wastes were found to be $1.56 \%$ phosphorus, $3.89 \%$ calcium, and $0.63 \%$ potassium. Micro nutrient elements were found to be 27.948 $\mathrm{mg} / \mathrm{kg}$ iron, $446 \mathrm{mg} / \mathrm{kg}$ manganese, and $393 \mathrm{mg} / \mathrm{kg}$ zinc. The researchers suggested the use of the mentioned aquaculture wastes with high element contents in organic agriculture as the plant nutrient (Salazar and Saldana, 2007).

The effects of the apple pulp used as the organic material was determined on some fertility characteristics of the soil (Yllmaz and Alagöz, 2009). Increasing amounts of apple pulp (1, 2 and 4 tone/da) showed significant increase in the organic material, $\mathrm{N}, \mathrm{P}, \mathrm{Fe}, \mathrm{Mn}$, and $\mathrm{Cu}$ contents of soil in the experiment area.

A study was conducted in France to determine the necessity of absolute use of farmyard manure in order to increase the organic material of the agricultural soils (Le villo et al., 2004).

The effects of vermicompost as organic material on the yield of red onion (Allium cepa L.) were analyzed in a research, in Azerbaijan. For this purpose, increasing amounts of vermicompost (2, 4, 6 tones/ha) were tested. The highest yield, protein and ascorbic acid values were obtained from the parcel where the highest dose (6 tone/ha) of vermicompost was applied (Bai and Malakouti, 2007). The need for the dissemination of the organic fertilizers in agriculture was obtained at the end of the research.

The effects of different organic materials on some nutrient elements, quality parameters and yield characteristic of the spinach (Spinacea oleracea L.) were determined in study where farmyard manure and organic materials commercially named bioform and perlhumus were applied together. The results showed that fertilizer applications significantly increased the yield, $\mathrm{N}, \mathrm{P}, \mathrm{K}, \mathrm{Ca}, \mathrm{Mg}, \mathrm{Fe}, \mathrm{Cu}, \mathrm{Zn}$ and $\mathrm{Mn}$ contents of the plants compared to controls (Tepecik et al., 2012).

Increasing amounts of aquaculture waste and vermicompost were applied to lettuce (Lactuca sativa L. var. crispa) in order to determine the effects of them on plant yield in greenhouse experiment. Increasing amounts of aquaculture and vermicompost significantly enhanced the plant yield, fresh weight, plant diameter, leaf number, leaf length and width. While the aquaculture application did not change $\mathrm{Fe}$ and $\mathrm{Mn}$ content of the plant, they were increased by the application of vermicompost together with aquaculture (Adiloğlu et al., 2016).

The effects of increasing amounts of pellet farmyard manure application on the mineral nutrition of the rye plant (Secale cerale L.) were determined in this study.

\section{MATERIALS and METHODS}

In this study, a greenhouse pot experiment were established using rye (Secale cerale L.) as plant material. Overall, $300 \mathrm{cc}$ in volume plastic pots were filled with soil samples taken from Application and Research area of Tekirdağ Namık Kemal University Faculty of Agriculture. Three replicates of 5 different farmyard manure doses $\left(\mathrm{FM}_{0}: 0 \%, \mathrm{FM}_{1}: 4 \%, \mathrm{FM}_{2}, 8\right.$ $\%, \mathrm{FM}_{3}: 12 \%$ and $\mathrm{FM}_{4}: 16 \%$ ) were applied to pots. The aforementioned organic fertilizer was mixed well with soil one month before sowing. After thirty days rye seeds (Secale cereale L.) were sown into the pots and nitrogen (14 $\left.\mathrm{kg} \mathrm{N} \mathrm{da}^{-1}\right)$, phosphorus $\left(8 \mathrm{~kg} \mathrm{P}_{2} \mathrm{O}_{5} \mathrm{da}^{-}\right.$ 1 and potassium ( $5 \mathrm{~kg} \mathrm{~K}_{2} \mathrm{O} \mathrm{da}^{-1}$ ) applied to each pot from $\mathrm{NH}_{4} \mathrm{NO}_{3}$ and $\mathrm{KH}_{2} \mathrm{PO}_{4}$ fertilizers. Into each pot, 20 seeds were sown and dilution was applied to have homogeneous 15 plants growth. After two months of growing, plants were harvested, dry matter yield were determined (Kacar and Inal, 2010). The results were evaluated and the effects of increased amounts of farmyard manure doses on some macro and micro nutrient elements of plant growth were investigated. determined

Some physical and chemical characteristics of the farmyard manure used in this study were as follows: $\mathrm{pH}: 7.50-9.50$, EC: $7.40 \mathrm{dS} / \mathrm{m}$, organic matter: $40 \%$, total (humic + fulvic) acid: $5 \%$, total phosphorus $\left(\mathrm{P}_{2} \mathrm{O}_{5}\right): 1.50 \%$, soluble potassium $\left(\mathrm{K}_{2} \mathrm{O}\right): 1.50 \%$, carbon/nitrogen ratio $(\mathrm{C} / \mathrm{N}): 8.90$, humidity: $20 \%$. These results were given in some information on farmyard manure bag.

The $\mathrm{pH}$, salt, lime, organic matter, available phosphorus, exchangeable potassium, calcium and magnesium contents (Sağlam, 2012), some available trace elements ( $\mathrm{Fe}, \mathrm{Cu}, \mathrm{Zn}, \mathrm{Mn}$ ) contents (Lindsay and Norvell, 1978), and texture (Tuncay, 1994) of the soil analyses were conducted. Nitrogen, $\mathrm{P}, \mathrm{K}, \mathrm{Ca}, \mathrm{Mg}$, $\mathrm{Fe}, \mathrm{Cu}, \mathrm{Zn}$ and $\mathrm{Mn}$ contents of the plants were determined according to Kacar and İnal (2010). Variance analyses of results were performed in MSTAT 3.00/EM software, and the means were compared with LSD test at 5\% significance level (Düzgüneş et al., 1987).

\section{RESULTS and DISCUSSION}

\section{Some Physical and Chemical Properties of Experiment Soil}

Some physical and chemical properties of the soil sample are given in Table 1. 
Table1. Some physical and chemical properties of the soil sample

Tablo1. Toprak örneğinin bazı fiziksel ve kimyasal özellikleri

\begin{tabular}{ll}
\hline Soil property & Analysis result \\
\hline $\mathrm{pH}$ & 7.23 \\
$\mathrm{EC} \times 10^{6}$ & 241 \\
Lime, \% & 2.80 \\
Organic matter, \% & 0.71 \\
Available phosphorus, $\mathrm{P}_{2} \mathrm{O}_{5}, \mathrm{~kg} / \mathrm{da}$ & 9.25 \\
Exchangeable, $\mathrm{K}_{2} \mathrm{O}, \mathrm{kg} / \mathrm{da}$ & 41.68 \\
Exchangeable, $\mathrm{Ca}, \%$ & 1.51 \\
Exchangeable, $\mathrm{Mg}, \%$ & 0.18 \\
Available $\mathrm{Mn}, \mathrm{mg} / \mathrm{kg}$ & 12.32 \\
Available $\mathrm{Cu}, \mathrm{mg} / \mathrm{kg}$ & 3.74 \\
Available $\mathrm{Fe}, \mathrm{mg} / \mathrm{kg}$ & 4.83 \\
Available $\mathrm{Zn}, \mathrm{mg} / \mathrm{kg}$ & 0.41 \\
Texture class & Clay (C) \\
\hline
\end{tabular}

The Table 1 shows that the soil is in neutral reaction, salt-free, has low lime, insufficient organic matter, medium level of available phosphorus, changeable $\mathrm{K}$, $\mathrm{Ca}, \mathrm{Mg}$, and sufficient available $\mathrm{Fe}, \mathrm{Cu}$ and $\mathrm{Mn}$, but insufficient Zn (Karaman et al., 2012a). Moreover, the texture of the soil is clay.

The effects of farmyard manure application on dry matter amount of the rye plant

The effects of the increasing doses of farmyard manure application on rye (Secale cerale L.) plant dry matter yield are presented in the Table 2 .

Table 2. The effect of farmyard manure application on dry matter yield of rye plant,

Tablo 2. Ciftlik gübresi uygulamasının çavdar bitkisinde kuru madde miktarna olan etkisi

\begin{tabular}{ll}
\hline Farmyard manure dose & Dry matter yield, gr pot ${ }^{-1}$ \\
\hline $\mathrm{FM}_{0}: \% 0$ & $2.26^{*} \mathrm{~b}^{* *}$ \\
$\mathrm{FM}_{1}: \% 4$ & $3.46 \mathrm{~b}$ \\
$\mathrm{FM}_{2}: \% 8$ & $5.11 \mathrm{ab}$ \\
$\mathrm{FM}_{3}: \% 12$ & $6.35 \mathrm{a}$ \\
$\mathrm{FM}_{4}: \% 16$ & $6.62 \mathrm{a}$ \\
\hline
\end{tabular}

*: values average of three replications, $* *$ : significant at the level of $5 \%$

Results revealed that application of increasing amounts of farmyard manure to rye, dry matter yield of the plant increased $(\mathrm{p}<0.05)$ (Table 2). The increase in the dry plant weight with addition of increasing amounts of organic material to the soil is an expected situation when the insufficient amount of organic matter in the experimental soil is taken into account.

Many previous researches indicated the increase of plant dry weight because of addition of increasing amounts of organic matter to soils, which were insufficient in organic matter (Stumpe et al., 2000, Sağlam et al., 2012, Adiloğlu et al., 2016).

Effects of Farmyard Manure Application on Some Macro Nutrient Element Contents of Rye Plant

The effects of increasing amounts of farmyard manure on some macro nutrient elements of the rye (Secale cerale L.) are given in Table 3.

There was no significant change among the doses of the applied of increasing amounts of manure in terms of the $\mathrm{Ca}$ and $\mathrm{Mg}$ contents of the rye plant (Secale cerale L.) compared to control. However, the N, P, K contents of the plant increased significantly with increasing amounts of farmyard manure compared to the control.

The reason of this situation might be because of the insufficient organic matter, sufficient $\mathrm{P}$ and changeable $\mathrm{K}, \mathrm{Ca}$ and $\mathrm{Mg}$ were available. Moreover, the duration of the experiment could have been short resulting a plant harvest before reaching to full harvest level.

The results of a research conducted on rye (Secale cerale L.) with increasing amounts of leonardite as the organic material showed that the effects of this organic material on $\mathrm{N}, \mathrm{P}, \mathrm{K}, \mathrm{Ca}$ and $\mathrm{Mg}$ contents of the plant varied while plant nutrient element contents usually increased (Adiloğlu et al., 2018).

According to Werner (1997), addition of increasing amounts of organic fertilizer to the soil increased the availability of some macro nutrient elements such as $\mathrm{N}, \mathrm{P}$, and $\mathrm{K}$ in the soil and in the plant.

Effects of the Farmyard Manure Application on Some Trace Element Contents of Rye Plant

The effects of increasing amounts of farmyard manure on some trace elements $(\mathrm{Fe}, \mathrm{Cu}, \mathrm{Zn}$ and $\mathrm{Mn}$ ) of rye (Secale cerale L.) are given in Table 4 . Increasing amounts of farm manure positively affected and significantly increased $(\mathrm{P}<0.05)$ the trace elements ( $\mathrm{Fe}, \mathrm{Cu}, \mathrm{Zn}$ and $\mathrm{Mn}$ ) of the rye compared to the control condition.

In a research by Alam et al. (2007) increasing amounts of vermicompost, which is an organic fertilizer, enhanced the contents of some trace elements of the potato plant. The results of the mentioned research are consistent with the results of this study.

A research conducted in Chile showed that increasing amounts of organic fertilizer applications significantly increased some trace elements such as $\mathrm{Fe}, \mathrm{Zn}, \mathrm{Mn}$ in plants (Celis and Sandoval, 2010).

Another related research found that different organic materials applied to lettuce significantly increased some trace elements including Fe and Mn (Adiloğlu et al., 2016). 
Table 3. The effects of farmyard manure application on some macro element $(\mathrm{N}, \mathrm{P}, \mathrm{K}, \mathrm{Ca}, \mathrm{Mg})$ contents of rye plant, \%,

Tablo 3. Ciftlik gübresi uygulamasının çavdar bitkisindeki bazı makro elementler (N, $P, K, C a, M g$ ) üzerine etkisi, \%

\begin{tabular}{llllll}
\hline Farmyard manure dose & $\mathrm{N}^{* *}$ & $\mathrm{P}$ & $\mathrm{K}$ & $\mathrm{Ca}$ & $\mathrm{Mg}$ \\
\hline $\mathrm{FM}_{0}: 0 \%$ & $2.83^{*} \mathrm{~b}$ & $0.23 \mathrm{~b}^{* * *}$ & $5.33 \mathrm{~b}$ & $0.96 \mathrm{~ns}$ & $0.10 \mathrm{~ns}$ \\
$\mathrm{FM}_{1}: 4 \%$ & $4.33 \mathrm{a}$ & $0.52 \mathrm{a}$ & $6.22 \mathrm{a}$ & $1.33 \mathrm{~ns}$ & $0.15 \mathrm{~ns}$ \\
$\mathrm{FM}_{2}: 8 \%$ & $4.76 \mathrm{a}$ & $0.66 \mathrm{a}$ & $6.62 \mathrm{a}$ & $1.58 \mathrm{~ns}$ & $0.16 \mathrm{~ns}$ \\
$\mathrm{FM}_{3}: 12 \%$ & $4.86 \mathrm{a}$ & $0.83 \mathrm{a}$ & $6.88 \mathrm{a}$ & $1.41 \mathrm{~ns}$ & $0.14 \mathrm{~ns}$ \\
$\mathrm{FM}_{4}: 16 \%$ & $4.83 \mathrm{a}$ & $0.82 \mathrm{a}$ & $6.79 \mathrm{a}$ & $1.43 \mathrm{~ns}$ & $0.12 \mathrm{~ns}$ \\
\hline
\end{tabular}

*: values average of three replications, $* *$ : each element was evaluated individually,

$* * *$ : significant at the level of $5 \%$.

Table 4. The effects of farmyard manure application on some trace element ( $\mathrm{Fe}, \mathrm{Cu}, \mathrm{Zn}$ ve $\mathrm{Mn}$ ) contents of rye plant, $\mathrm{mg} / \mathrm{kg}$,

Tablo 4. Çiftlik gübresi uygulamasının çavdar bitkisindeki bazı mikro elementler ( $\mathrm{Fe}, \mathrm{Cu}, \mathrm{Zn}$ ve $\mathrm{Mn}$ ) üzerine etkisi, $\mathrm{mg} / \mathrm{kg}$,

\begin{tabular}{lllll}
\hline Farmyard manure dose & $\mathrm{Fe}^{* *}$ & $\mathrm{Cu}$ & $\mathrm{Zn}$ & $\mathrm{Mn}$ \\
\hline $\mathrm{FM}_{0}: \% 0$ & $39.33^{*} \mathrm{~b}$ & $8.83 \mathrm{c}^{* * *}$ & $12.82 \mathrm{c}$ & $80.37 \mathrm{c}$ \\
$\mathrm{FM}_{1}: \% 4$ & $110.13 \mathrm{a}$ & $11.95 \mathrm{~b}$ & $20.35 \mathrm{~b}$ & $92.52 \mathrm{~b}$ \\
$\mathrm{FM}_{2}: \% 8$ & $117.16 \mathrm{a}$ & $16.26 \mathrm{a}$ & $23.86 \mathrm{~b}$ & $94.06 \mathrm{~b}$ \\
$\mathrm{FM}_{3}: \% 12$ & $119.93 \mathrm{a}$ & $16.12 \mathrm{a}$ & $30.64 \mathrm{a}$ & $105.59 \mathrm{a}$ \\
$\mathrm{FM}_{4}: \% 16$ & $112.40 \mathrm{a}$ & $16.76 \mathrm{a}$ & $31.52 \mathrm{a}$ & $106.64 \mathrm{a}$ \\
\hline
\end{tabular}

*: values average of three replications, **: each element was evaluated individually, ***: significant at the level of $5 \%$.

\section{CONCLUSION}

The results of this study revealed that a significant increase in dry mass of the rye (Secale cerale L.) were observed when increasing amounts of farmyard manure were used.

Moreover, N, P, K contents of the plant was seen significantly higher than the control by increasing amounts of manure. However, the $\mathrm{Ca}$ and $\mathrm{Mg}$ contents of the plant were not significantly different with the same applications. The $\mathrm{Fe}, \mathrm{Cu}, \mathrm{Zn}$ and $\mathrm{Cu}$ contents of the rye were also significantly increased with increased amount of farmyard manure.

The use of organic fertilizers to meet the needed plant nutrient element of the cultivars has been rapidly increased worldwide. Intense use of chemical fertilizer mostly degenerated the nutrition balance, resulting production of unhealthy products, which started threaten the human health seriously all over the world.

It has been an obligation to disseminate the use of organic materials such as farm manure in the agriculture in order to increase the organic matter content of our soils. The more dissemination of organic fertilizer use in agriculture would enhance the organic matter content of the soils, which may even recover some quality parameters of the plants that were destroyed by the intense use chemical fertilizers.

The absolute need for the use of farm manure was revealed with this study. The importance of dissemination of the organic fertilizer use becomes more obvious when the organic matter insufficiency of soils of Turkey is taken into account.

\section{Competing interests and Acknowledgements}

Authors have declared that no competing interests exist.

\section{ACKNOWLEDGMENTS}

This study was supported by Scientific Research Project Comission (BAP) of Namık Kemal University under the project number: NKUBAP. 03.GA.16.075.

\section{REFERENCES}

Adiloğlu A, Bellitürk K, Adiloğlu S, Solmaz Y 2018. The effect of Increasing Leonardit Applications on Dry Matter Yield and Some Nutrient Elements Contents of Rye (Secale cerale L.) plant. Eurasian Journal of Forest Science, 6 (1): 44-51.

Adiloğlu A, Eryılmaz Açıköz F, Adiloğlu S, Solmaz Y 2016. Artan Miktarlarda Akuakültür Atığ Uygulamasinin Salata (Lactuca sativa L. var. crispa) Bitkisinin Bazı Makro ve Mikro Bitki Besin Elementi İçerikleri Üzerine Etkisi. Tekirdağ Ziraat Fak. Dergisi, 13 (2): 96-101.

Alam MN, Jahan MS, Ali MK, Ashraf MA, Islam MK 2007. Effect of Vermicompost and Chemical Fertilizers on Growth, Yield and Yield Components of Potato in Barind Soils of Bangladesh. J. Appl. Sci. Res., 3 (12): 1879-1888.

Bai BA, Malakouti MJ 2007. The Effect of Different 
Organic Manures on Some Yield and Yield Quality Parameters in Onion. Iran Soil and Water Sciences Journal, 21 (1): 43-33.

Celis J, Sandoval M 2010. Agricultural Potential of Salmon Wastes Used as Organic Fertilizer on Two Chilean Degraded Soils. 19th World Congress of Soil Science, Soil Solutions for a Changing World 1 - 6 August, Brisbane, Australia.

Doğru, A, Darçın ES, Tutar A, Dizman M, Koç Y 2012. Potasyum Humatin Misır (Zea mays L.) Bitkisinin Büyümesi Üzerine Etkileri. SAÜ Fen Edebiyat Dergis 14 (1): 83-93.

Düzgüneş O, Kavuncu O, Kesici T, Gürbüz F 1987. Araştırma ve Deneme Metodları. A.Ü. Ziraat Fakültesi Yayınları, No: 1021, Ankara.

Edmeades D 2003. The Long Term Effects of Manures and Fertilizers on Soil Productivity and Quality: A review. Nutrient Cycling in Agroecosystems, 66: 165- 180.

Kacar B, İnal A 2010. Bitki analizleri. Nobel Yayın, No: 849, 659s, Ankara.

Karaman MR, Şahin S, Geboloğlu N, Turan M, Güneş A, Tutar A 2012. Humik Asit Uygulaması Altında Farklı Domates (Lycopersicon esculentum L.) Çeşitlerinin Demir Alım Etkinlikleri. SAÜ Fen Edebiyat Dergisi 14 (1): 301-308.

Karaman MR, Adiloğlu A, Brohi R, Güneş A, İnal A, Kaplan M, Katkat V, Korkmaz A, Okur N, Ortaş İ, Saltalı K, Taban S, Turan M, Tüfenkçi Ş, Eraslan F, Zengin M, 2012a. Bitki Besleme. Dumat Ofset, Matbaacılık San. Tic. Ltd. Şti., 1080 s, Ankara.

Le Villo M, Arruays D, Deslais W, Clegeot D, Daroussin J, Bissonnais Y 2004. Interest of the Compost as a Source of Organic Matter to Restore and Maintain Physical Properties of French Soils. $\begin{array}{lllll}\text { Symposium } & \text { No: } & \text { 57, } & \text { Paper } & \text { No: }\end{array}$ http://www.sfst.org.

Lindsay WL, Norvell WA 1978. Development of a DTPA Soil Test for Zinc, Iron, Manganase and Copper, Soil Sci. Soc. Am. J., 42: 421- 428.

Sağlam MT, Özel EZ, Bellitürk K 2012. İki Farklı Tekstüre Sahip Yoprakta Leonardit Organik Materyalinin Mısır Bitkisinin Azot Alımına Etkisi. SAÜ Fen Edebiyat Dergisi, 14 (1): 383- 391.

Sağlam MT 2012. Toprak ve Suyun Kimyasal Analiz Yöntemleri. Namık Kemal Üniversitesi, Yayın No: 2 , Tekirdağ.

Salazar FJ, Saldana RC 2007. Characterization of Manures from Fish Cage Farming in Chile. Bioresource Technology 98: 3322-3327.

Stumpe H, Garz J, Schliephake W, Wittenmayer L, Merbach W 2000. Effects of Humus Content, Farmyard Manuring and Mineral N Fertilization on Yield and Soil Properties in a Long Term Trial. J. of Plant Nutrition and Soil Science, 163 (6): 657662.

Tepecik M, Ongun AR, Okur B, Bozkalfa K, Eşiyok D 2012. Farklı Organik Materyallerin Ispanak Bitkisinin (Spinacea oleracea L.) Bazı Besin Elementi, Kalite Öğeleri ve Verim Özellikleri Üzerine Etkisi. SAÜ Fen Edebiyat Dergi., 14 (1): 243- 252.

Tuncay H 1994. Toprak Fiziği Uygulama Kılavuzu. E. Ü. Ziraat Fakültesi Teksir No: 29, İzmir.

Werner M 1997. Earthworm Team up with Yard Trimmings in Orchards. Biocycle, 38 (6): 64-65.

Yllmaz E, Alagöz Z 2009. Organik Materyal (Elma posası) Uygulamasının Toprağın Bazı Verimlilik Özelliklerine Etkisi. Akdeniz Üniversitesi Ziraat Fakültesi Dergisi, 22 (2): 233- 250. 